\title{
PROMOTING PUBLIC HEALTH: BENEFITS AND CHALLENGES OF A EUROPEANWIDE RESEARCH CONSORTIUM ON STUDENT HEALTH
}

\author{
Walid El Ansari ${ }^{1}$, Annette E. Maxwell ${ }^{2}$, Rafael T. Mikolajczyk ${ }^{3}$, Christiane Stock ${ }^{4}$, Vihra Naydenova ${ }^{3}$, \\ Alexander Krämer ${ }^{3}$ \\ ${ }^{1}$ Faculty of Sport, Health \& Social Care, University of Gloucestershire, Gloucester, United Kingdom \\ 2Division of Cancer Prevention \& Control Research, School of Public Health/Jonsson Comprehensive Cancer Center, University of California, \\ Los Angeles, USA \\ ${ }^{3}$ Department of Public Health Medicine, School of Public Health, University of Bielefeld, Bielefeld, Germany \\ ${ }^{4}$ Unit for Health Promotion Research, University of Southern Denmark, Esbjerg, Denmark
}

\begin{abstract}
SUMMARY
Aims: The purpose of this paper is to highlight some of the benefits and challenges when undertaking research across several countries comprising diverse ethnic, lingual and historically different communities.

Methods: Literature review and experiences of the researchers who participated in the Students' Health Inquiry, as regards the benefits and the challenges that can emerge when conducting collaborative research. The Delphi technique was employed to reach consensus on and prioritise the emerging challenges and suggested solutions.

Results: Challenges of research consortia include the preparatory work before the study, the ownership of the data and dissemination of results, as well as methodological, financial, operational, and structural challenges. These are described, each challenge is further broken down in its subcomponents, examples are given, and potential solutions are suggested.

Conclusions: If challenges can be prevented or solved, the benefits of research consortia include greater generalisability of findings, and more comprehensive understanding of the issues than would be possible with a single-site study. There is also an increased probability to bring about policy changes and programmatic adjustments. Cross-national research consortia can contribute to reduction in the inequality of resources and research opportunities in the collaborating countries. Research consortia deserve the attention of funding agencies. They are capable of bringing about synergies that result from working collaboratively together of large multi-disciplinary team of investigators who share their strengths, disciplines and expertise in order to bear on the same research issue in multiple countries and diverse populations.
\end{abstract}

Key words: student health, research consortia, public health

Address for correspondence: Walid El Ansari, Professor of Public Health, University of Gloucestershire, Faculty of Sport, Health \& Social Care, Oxstalls Campus, Oxstalls Lane, Gloucester, Gloucestershire GL2 9HW, United Kingdom. E-mail: walidansari@glos.ac.uk

\section{INTRODUCTION}

Research consortia that undertake cross-national research are becoming increasingly popular. A 'research consortium' is a group of individuals and their organisations working collaboratively together in order to attract funding and design and implement research over one or several countries and sites that would otherwise be not achievable (1). Such consortia have proved to be effective in many clinical or epidemiologic investigations that span several countries or sites. They have pursued inquiries of student's health behaviour (2), cancer prevention and control strategies (3), parenting practices (4), health care systems (5), or alternatively communicable diseases $(6,7)$, midwifery (8), partnership working (9) or quality-of-life research (10). In this paper, a research consortium undertaking international comparisons of the health of university students is employed as an example in order to illustrate a range of specific aspects that are associated with the cooperative nature of such projects. Whilst differences in mortality across European countries are well documented (11-14), the differences in somatic symptoms and psychosomatic health across Europe have received little attention (2). Hence there have been calls for comparisons of the health profiles among populations of young adults across several European countries (2, 15-17).

University students constitute one group of young adults that is suitable for comparative investigations. Students are certainly accessible and are likely to participate in studies since many are aware of the importance of research. Moreover, as health and health behaviours are subject to demographic factors, the study of individual country effects can be better disentangled in a group characterised by restricted variations in terms of education, socioeconomic status, and age (2). Finally, students represent the future leaders of their countries and are often described as early adopters 
and promoters of new behaviours. If they can be influenced to adopt healthier lifestyles, they might function as multipliers to their extended families and surrounding communities. Hence university students are an appropriate sample for examining a range of risk taking and conversely, health promoting behaviours and for testing new and promissing health promotion programmes.

The purpose of this paper is to highlight some of the benefits and challenges encountered when undertaking research across several countries comprising diverse ethnic, lingual and historically different communities. The specific aims are: to describe a European consortium undertaking cross-national research on student health in several Western and Eastern European countries; to highlight some of the benefits of research consortia such as ours; to identify and illustrate the range of challenges associated with such consortia; and to suggest strategies on how to prevent/ overcome these challenges.

\section{METHODS}

The idea of this paper was developed at a two day workshop funded by the German Academic Exchange Service (DAAD) with members of the Cross National Student Health Study Consortium that was convened in Bielefeld in April 2006. The team members' collective experiences range from collaborating with or managing such consortia, conducting research across several European countries or in their own countries, surveying student health behaviours across multiple institutions, faculties and colleges employing different languages, or alternatively building research partnerships with multiple and diverse communities (see 2, 9, 18-24). As such the group had previously dealt with many challenges related to a variety of features that confront multi-country research consortia.

Hence, initial 'brainstorming' sessions were held with the members of the research consortium described in this paper (face-to-face discussions and subsequent e-mail and telephone communications). The purpose of the sessions was to explore the team members' perceptions of the variety of challenges that they collectively faced when undertaking similar research across seven countries and to suggest possible solutions. After the preliminary 'brainstorming' sessions were completed, the first author clustered the emerging themes and concerns into categories. Originally, there was an extended list of topics. These topics and clusters acted as an early working document that was then disseminated several times to the team members. The aim was to use the Delphi technique in order to distil the list by employing several rounds of refinements (25). The Delphi method is a group agreement method that was developed to identify goals and establish priorities on the basis of consensus and pooled judgement (26-28). However, in this review, the Delphi technique was somewhat customized (29), as the team members were not asked to rate the items and provide scores as in the classical procedure (30). Rather the aim was to highlight the issues that they felt were significant. Several rounds of alterations were undertaken, whereby the team participants were asked to respond to issues that emerged initially. After each round of fine tuning, topics were scrutinised, and subsequently eliminated from or added to the table anonymously in each stage of the inquiry. In this way, when no additional challenges were added, the more pertinent issues were progressively condensed and given attention while the less influential ones were progressively abandoned in final version. When consensus was reached a literature review was undertaken in order to complement the emerging concerns with any other published challenges that were pertinent to the effective working of research consortia.

The topics that emerged included operational and structural challenges, as well as methodological and financial ones. The group also reported challenges that had to do with the preparatory work that is required for European survey research. Finally the group had previously also dealt with the thorny issues of data ownership and authorship that confront such multi-country research consortia. These sets of challenges and possible solutions are addressed in this paper.

\section{DESCRIPTION OF THE CROSS-NATIONAL STUDENT HEALTH STUDY RESEARCH CONSORTIUM}

Two initiatives inspired our research on students' health. One was the Health-Behaviour in School-aged Children study (http:// www.hbsc.org). Another inspiration came from the existence of health centres at US American colleges and universities and their activities to influence students' health-related lifestyle. The first study on students' health and health behaviour at the University of Bielefeld was completed in 1996. The results of this survey were presented at European meetings (e.g. the conference of the European Public Health Association), which raised the interest of other researchers to conduct comparative studies at their institutions. The initial cross-national group consisted of four partners, and between 2000 and 2006 new researchers joined the consortium. Hence the research was being extended to more countries.

Table 1 depicts the current participating institutions and the sample sizes generated from each site. Between 1996 and 2006, universities from seven European countries had participated in the research. In three countries (Germany, Spain, and Lithuania), a second survey was undertaken about 3 or 4 years after the initial baseline survey, hence following up particular student cohorts with the same questionnaire. Such follow-ups are important in order to detect any trends in students' risk-taking or health-conducive behaviours as well as their health promoting practices. Currently the consortium is establishing dialogues with new potential partners in order to expand the geographical regions that are participating in this research initiative. Such activities will be useful in generating larger datasets, which will reflect student health behaviours in more European countries.

\section{THE BENEFITS OF RESEARCH CONSORTIA}

Many benefits have been cited for research consortia (3, 31, 32 ). Through their numerous investigative teams (5) and access to large and diverse sample populations (33), consortia like the one described in this paper are critical resources for exploring somatic symptoms and psychosomatic health and subsequently evaluating health promotion interventions.

Research consortia spanning many countries have the advantage of increased size and diversity of the potential study population, as well as variation in their risk taking practices or risk averting lifestyles that are essential for the study of student health 
Table 1. Countries and institutions participating in the Cross-National Student Health Study between 1996 and 2006

\begin{tabular}{|l|l|l|}
\hline Country & Institutions & Sample size \\
\hline Germany 1996 & University of Bielefeld, Bielefeld & 650 \\
\hline Germany 1998 (follow-up) & University of Bielefeld, Bielefeld & 163 \\
\hline Spain 1999 & $\begin{array}{l}\text { Navarra Public University, Pamplona } \\
\text { University of Alicante, Alicante }\end{array}$ & 662 \\
\hline Lithuania 2000 & $\begin{array}{l}\text { Kaunas University of Medicine } \\
\text { Vytautas Magnus University } \\
\text { Lithuanian University of Law } \\
\text { Lithuanian Academy of Physical Education } \\
\text { Lithuanian University of Agriculture } \\
\text { Kaunas University of Technology }\end{array}$ & \multirow{2}{*}{1031} \\
\hline Spain 2001 (follow-up) & Navarra Public University, Pamplona & \\
\hline Turkey 2004 & Hacettepe University, Ankara & 370 \\
\hline Lithuania 2004 (follow-up) & Kaunas University, Kaunas & 1037 \\
\hline Poland 2005 & Catholic University of Lublin, Lublin & 431 \\
\hline Bulgaria 2005 & Sofia University, Sofia & 591 \\
\hline Denmark 2005 & University of Southern Denmark, Esbjerg & 709 \\
\hline Germany 2005 & University of Bielefeld, Bielefeld & 548 \\
\hline
\end{tabular}

behaviours. These variations that are characteristic of research that examines clusters of sites (34) 'elevates the statistical power of the analyses and hence the validity and reliability of the findings' (35). Besides larger sample sizes and better generalisability that is grounded in wider multi-country surveys, there is also extensive sharing of expertise and resources across the study teams, thereby exchanging valuable skills as well as minimising the duplication of studies (33). These and other benefits of cross-national research consortia are summarized in Table 2, including aspects of funding, synergy, dissemination and translation of research findings into health policy.

In sum, multi-country multi-centre research consortia offer several benefits in addressing key research questions about student health that cannot be addressed in a single-site study. These include: (1) the maintenance of databases with a rich array of information on student health and risk taking behaviours, (2) economy of scale regarding the efforts required for health assess- ment and health promotion activities, (3) a variety of structures and health policies that can promote or hinder health promotion at the university setting in different countries can be examined, and (4) epidemiologic comparisons among institutions, countries and student populations can be conducted.

\section{DISCUSSION OF RESEARCH CONSORTIA: CHAL- LENGES, IMPLICATIONS AND POSSIBLE SOLU- TIONS}

Table 3 outlines some of the challenges that could confront research consortia who are instigating or developing their research (and required funding), as well as their probable implications. It also illustrates the possible solutions that are essential in order that such consortia remain viable and relevant to the populations that they investigate and to the researchers who populate

Table 2. Benefits of collaborative European research consortia

\begin{tabular}{|l|l|}
\hline Benefit & Example \\
\hline Scientific gains & $\begin{array}{l}\text { Increased size and diversity of the study population, variations in risk taking practices or risk averting life styles, } \\
\text { and variations in health policies and structural settings contribute to better understanding of issues. }\end{array}$ \\
\hline Expertise of investigator team & $\begin{array}{l}\text { Investigators complement each other due to multiple theoretical approaches, disciplines, educational backgrounds } \\
\text { and strengths. }\end{array}$ \\
\hline Funding & $\begin{array}{l}\text { Specific funding mechanisms are available for Europeanwide research consortia that are not open for individual } \\
\text { studies. }\end{array}$ \\
\hline Generalisability & Larger sample size, multiple countries, settings, health strategies and social environments increase generalisability. \\
\hline Synergy & $\begin{array}{l}\text { Sharing of expertise and resources. Lessons learned in one country may be applicable to other countries. Instead } \\
\text { of developing interventions de novo for the same health problem in each country, investigators may be able to adapt } \\
\text { an intervention that was successful in one country to another setting. }\end{array}$ \\
\hline $\begin{array}{l}\text { Determining environmental/ social } \\
\text { influences }\end{array}$ & $\begin{array}{l}\text { Studying similar populations and interventions in different countries can examine the impact of environmental factors } \\
\text { (e.g. health policy or culture) and social influences (e.g. social norms or migration) }\end{array}$ \\
\hline Publication/ dissemination & $\begin{array}{l}\text { Comparative results from more then one European country raise a higher interest in the scientific community which } \\
\text { enhances the publication of manuscripts in higher ranked journals. }\end{array}$ \\
\hline Translation of research findings & $\begin{array}{l}\text { Findings from Europeanwide research consortia are well placed to contribute to Europeanwide policy with higher } \\
\text { probability of bringing about required change. }\end{array}$ \\
\hline
\end{tabular}


these consortia. Collectively, the challenges addressed an array of concerns. Broadly categorised, these included preparation, methodological, financial, operational, structural, ownership and dissemination challenges. However, during the process of categorizing the challenges, we often experienced 'spill-overs', where any particular challenge would have multi-pronged implications. To cite an example, the issues of the stability of both the focus of the survey and the tool of the survey represent timefactor (methodological) challenges in their own right. However these time-factor issues have ramifications as new partners join the consortium and new research areas are explored which then represent operational challenges. Further, as new partners join they require to be communicated and coordinated and the structure of the consortium might change to accommodate these new needs which then represent structural challenges. Finally as these new scientists settle, they would need to be acknowledged, included in the publication plan and dissemination outputs which then represent ownership and dissemination challenges. Thus, Table 3 represents a simplification that does not take into account all possible scenarios and challenges.
The first set of challenges had to do with the preparatory work required before any multi-country study can commence. This included the selection of the topics of the research, as well as the issues surrounding the main aims of the proposed study (32). This set also included issues that were related "to not reinventing the wheel”, the planning of the research process, any present or likely future trends that could affect the research, as well as the choice of main working language of the consortium, and the need for early consultation with the potential stakeholders (3, 5). Solutions included thorough literature reviews in order to determine health issues that require further investigation; the involvement of all consortium members in providing input on relevant topics; and to obtain "buy in" from potential stakeholders early on. If there is not a common language that all consortium members can communicate in, it is essential to hire competent interpreters for meetings and conference calls. Equally important is to avoid domination by native or high proficient English speakers.

The second set of queries was related to a broad range of methodological challenges. This set embraced issues of the assessment instruments, sampling procedures and study protocols,

Table 3. European Research consortia: some challenges and solutions

\begin{tabular}{|c|c|c|}
\hline Challenge & Example/ Implication & Solutions \\
\hline \multicolumn{3}{|c|}{ 1. Preparatory work before the study } \\
\hline $\begin{array}{l}\text { Focus and main aims } \\
\text { of the study }\end{array}$ & $\begin{array}{l}\text { Have the main aims of the study been determined by all consortium } \\
\text { members? Why are comparisons between several countries useful? } \\
\text { Are relevant future developments considered? What are the social and } \\
\text { economic factors influencing health? Is the study innovative? }\end{array}$ & $\begin{array}{l}\text { Review the international literature on students' health. Agree } \\
\text { on topics that have not been investigated so far. } \\
\text { Agree with all consortium members for input on relevant } \\
\text { topics. }\end{array}$ \\
\hline $\begin{array}{l}\text { Planning of the } \\
\text { research process }\end{array}$ & $\begin{array}{l}\text { How will the study be financed? Will the study use quantitative or qualita- } \\
\text { tive methods or both? What is the best study design for the question/s } \\
\text { posed? Which research instruments will be selected? }\end{array}$ & $\begin{array}{l}\text { Brainstorm funding sources and apply for funding, possibly from } \\
\text { multiple sources. Agree on study design, research methodol- } \\
\text { ogy, and assessment instruments. }\end{array}$ \\
\hline $\begin{array}{l}\text { Language } \\
\text { of consortium }\end{array}$ & Is the consortium dominated by English-speaking members? & Hire interpreters for meetings and conference calls. \\
\hline $\begin{array}{l}\text { Consultation with } \\
\text { potential stakeholders }\end{array}$ & $\begin{array}{l}\text { Have all consortium members obtained "buy-in" from their administra- } \\
\text { tions and institutions? }\end{array}$ & $\begin{array}{l}\text { Communicate with the uni } \\
\text { members that are required }\end{array}$ \\
\hline \multicolumn{3}{|c|}{ 2. Methodological challenges } \\
\hline $\begin{array}{l}\text { Assessment instru- } \\
\text { ments (validity, } \\
\text { reliability, translations, } \\
\text { cultural issues, pilot } \\
\text { testing) }\end{array}$ & $\begin{array}{l}\text { What assessment instruments are available and in what languages? } \\
\text { Are they psychometrically sound? Have back and forth translations } \\
\text { been conducted? Can instruments capture country-specific features } \\
\text { in spite of standardization? Have pilot tests been conducted in each } \\
\text { participating country? Have some countries norms or laws that can } \\
\text { result in underreporting (smoking, alcohol, drugs?) }\end{array}$ & $\begin{array}{l}\text { When possible and appropriate, use instruments that have } \\
\text { been validated in different languages. Verify that translations } \\
\text { capture identical concepts. Discuss cultural aspects with } \\
\text { consortium partners. Pilot assessment instruments in each } \\
\text { country. Consider threat of underreporting when formulating } \\
\text { questions. }\end{array}$ \\
\hline $\begin{array}{l}\text { Sampling } \\
\text { (institutions, faculties } \\
\text { and students) }\end{array}$ & $\begin{array}{l}\text { Are participating universities comparable across countries? } \\
\text { Are participating faculties comparable (health sciences, law, engineer- } \\
\text { ing, social sciences, theology etc)? Can the same sampling design be } \\
\text { applied at all locations? Do the policies for attendance at lectures differ } \\
\text { between universities? Are informants who choose to participate different } \\
\text { from those who do not? }\end{array}$ & $\begin{array}{l}\text { Use adequate sampling techniques, but selected institution/s } \\
\text { must also be willing to participate. When data collection takes } \\
\text { place during a course, record whether attendance of the course } \\
\text { is mandatory. Specify eligibility criteria such as first/second year } \\
\text { students, etc. Collect information about non-responders. }\end{array}$ \\
\hline Ethical approval & $\begin{array}{l}\text { Are the regulations for conducting the study different across countries? } \\
\text { What are the financial charges and time lines of ethics committees? } \\
\text { Certain questions can be viewed unethical in some countries. }\end{array}$ & $\begin{array}{l}\text { Satisfy requirements of ethics committees in each country. } \\
\text { Committees could be more established/ stringent in some } \\
\text { countries. Costs need to be budgeted. }\end{array}$ \\
\hline $\begin{array}{l}\text { Response rate } \\
\text { (Standard procedures } \\
\text { to calculate response } \\
\text { rate; ways to increase } \\
\text { response rate) }\end{array}$ & $\begin{array}{l}\text { If data collection takes place in different settings, response rates } \\
\text { may be determined using different methods. Have mechanisms been } \\
\text { instilled to encourage high response rates? Is the respondent burden } \\
\text { reasonable? }\end{array}$ & $\begin{array}{l}\text { Clearly define what counts as non-response (blank or partly } \\
\text { completed questionnaires, students leaving the room, students } \\
\text { refusing to take a questionnaire). Provide informant incentives. } \\
\text { Keep survey length reasonable. Provide time for completion } \\
\text { during lectures. Choose responsible data collectors. }\end{array}$ \\
\hline Confidentiality & $\begin{array}{l}\text { Is there a common protocol for data storage that guarantees confi- } \\
\text { dentiality? }\end{array}$ & $\begin{array}{l}\text { Protect confidentiality through separating names and identifiers } \\
\text { or obtain data anonymously. }\end{array}$ \\
\hline
\end{tabular}




\begin{tabular}{|c|c|c|}
\hline $\begin{array}{l}\text { Data quality control } \\
\text { and back-up }\end{array}$ & $\begin{array}{l}\text { Is the data entry centralized or is it done at each country/institution? } \\
\text { What are the procedures for quality control? Are there mechanisms for } \\
\text { quality control before and after merging the individual country datasets? } \\
\text { What are the protocols for making back-up copies? }\end{array}$ & $\begin{array}{l}\text { If data entry takes place decentralised (i.e. at each research } \\
\text { site), then standardise the procedures for data entry, cleaning } \\
\text { and back-up. Data entry software that checks values and cross } \\
\text { examines variables can prevent data entry errors. }\end{array}$ \\
\hline Data access & Is the dataset easily accessible for all the partners? & Share data online (password protected) or by e-mail. \\
\hline $\begin{array}{l}\text { Data analyses } \\
\text { (standardization, } \\
\text { country comparisons, } \\
\text { socio-economic data, } \\
\text { homogeneity/stratifica- } \\
\text { tion, } \\
\text { innovative techniques, } \\
\text { joint analysis) }\end{array}$ & $\begin{array}{l}\text { Have the data analyses techniques been standardised across the } \\
\text { participating countries? Can differences in outcomes be attributed } \\
\text { to either the institution or the country? Cross-country comparisons of } \\
\text { socio-economic data are difficult because of different monetary systems } \\
\text { and cost of living. Are variables that pertain to the university collected? } \\
\text { Does the impact of socio-economic data differ between countries? Are } \\
\text { innovative statistical techniques needed? Are data homogenous enough } \\
\text { for a joint analysis or meta-analysis? }\end{array}$ & $\begin{array}{l}\text { Perform data analysis centrally or share data analysis tech- } \\
\text { niques, programs, and competencies. More than one university } \\
\text { per country is needed to separate the effect of institutions } \\
\text { and countries. Evaluate country-specific socio-economic } \\
\text { data within countries, ad relative rankings between countries. } \\
\text { Perform stratified analysis/analysis of interactions with country } \\
\text { as a variable. Complex modelling using either Bayesian ap- } \\
\text { proach or structural modelling equations may be necessary. } \\
\text { Prospectively planned pooled analysis is more flexible than } \\
\text { formal meta-analysis. }\end{array}$ \\
\hline $\begin{array}{l}\text { Time factor } \\
\text { (secular trends; loss } \\
\text { on follow-up; changing } \\
\text { focus of study, assess- } \\
\text { ment tools, investiga- } \\
\text { tors) }\end{array}$ & $\begin{array}{l}\text { Have secular trends in each country been considered in order that the } \\
\text { 'net' effects can be isolated? Can students be re-contacted for follow- } \\
\text { up assessments? Did the focus of the survey change due to emerging } \\
\text { interests in the scientific community (e.g., more focus on smoking in later } \\
\text { surveys)? Did the assessment tool remain constant or was it modified } \\
\text { based on knowledge gained from earlier work? Have some researchers } \\
\text { left while others with new interests joined the consortium? }\end{array}$ & $\begin{array}{l}\text { Estimate secular trends for longitudinal studies and cross- } \\
\text { sectional studies that take place in different years. } \\
\text { If feasible, collect participant's home address, registration } \\
\text { number, and e-mail/s. Carefully assess the cost-benefit of } \\
\text { amending the focus of the survey. Carefully assess the cost- } \\
\text { benefit of modifying the survey and consider leaving some } \\
\text { "core items" unchanged. }\end{array}$ \\
\hline \multicolumn{3}{|l|}{ 3. Financial Challenges } \\
\hline General finances & $\begin{array}{l}\text { Have proposals been submitted to } \\
\text { study that is unlikely to be funded } b\end{array}$ & naller \\
\hline $\begin{array}{l}\text { Fundii } \\
\text { tific ac }\end{array}$ & anned and conducted jointly in a coordinated & Secure adequate funding for joint scientific activities. \\
\hline $\begin{array}{l}\text { Adequate funding: } \\
\text { individual countries }\end{array}$ & $\begin{array}{l}\text { searchers in countries with less eco- } \\
\text { urope)? }\end{array}$ & $\begin{array}{l}\text { Low salaries affect the quality of researchers who are recruited } \\
\text { in some countries. }\end{array}$ \\
\hline Unequal resources & Are there sufficient resources (equipment) across countries? & Allocate additional resources in the plannin \\
\hline Fiscal/ tax years & riods before actual allocation of resources? & $\begin{array}{l}\text { Consid } \\
\text { across }\end{array}$ \\
\hline \multicolumn{3}{|c|}{ 4. Operational challenges: partnership working of research consortia } \\
\hline Planning & Have joint activities been planned across the participat & Plan joint activities proactively ratl \\
\hline $\begin{array}{l}\text { Participation } \\
\text { (Division of labour and } \\
\text { decision making) }\end{array}$ & $\begin{array}{l}\text { Do all consortium members actively participate? Is the workload } \\
\text { adequately distributed? Are organisational, operational and scientific } \\
\text { issues democratically decided upon? }\end{array}$ & $\begin{array}{l}\text { All consortium members need to have the interest and capacity } \\
\text { to participate. Workload needs to be distributed fairly, decision } \\
\text { making should not 'choke' activities. }\end{array}$ \\
\hline $\begin{array}{l}\text { Relationships between } \\
\text { members }\end{array}$ & members welcomed into the co & $\begin{array}{l}\text { Plan regul } \\
\text { research a }\end{array}$ \\
\hline \multicolumn{3}{|c|}{ 5. Structural challenges: the shape of the consortium } \\
\hline $\begin{array}{l}\text { Management, coordi- } \\
\text { nation and communi- } \\
\text { cation }\end{array}$ & $\begin{array}{l}\text { Is the consortium professionally ma } \\
\text { Who is responsible for initiating a } \\
\text { between the partners? }\end{array}$ & $\begin{array}{l}\text { Set up regular meetings and conference calls, distribute } \\
\text { minutes, agree on and enforce action points and timelines. } \\
\text { Specify responsibilities for coordinating center(s). }\end{array}$ \\
\hline Leadership & $\begin{array}{l}\text { Is there a competent and adequately resourced leadership established? } \\
\text { Are tasks and responsibilities clearly defined? }\end{array}$ & $\begin{array}{l}\text { Consortia need sound leadership with adequate support and } \\
\text { leadership skills }\end{array}$ \\
\hline \multicolumn{3}{|c|}{ 6. Ownership and dissemination challenges } \\
\hline Acknowledgement & How are consortia members and funding agencies acknowledged? & All members agree on acknowledgment paragraph. \\
\hline Ownership of data & $\begin{array}{l}\text { Who owns data from individual institutions, countries or the whole } \\
\text { consortium? }\end{array}$ & $\begin{array}{l}\text { All members agree on rules that clarify who has the right to } \\
\text { analyse which datasets. }\end{array}$ \\
\hline Publications & How do members plan publications? & $\begin{array}{l}\text { All members agree on outlines provided by lead authors prior } \\
\text { to manuscript preparation to prevent conflicts and duplication } \\
\text { of analyses. }\end{array}$ \\
\hline Authorship & How is authorship decided? & $\begin{array}{l}\text { Authorship issues are deliberated early and be premised on } \\
\text { contributions as per international requirements for author- } \\
\text { ship. }\end{array}$ \\
\hline $\begin{array}{l}\text { Dissemination } \\
\text { channel/s }\end{array}$ & $\begin{array}{l}\text { Do the targeted journal/s consider manuscripts with more than } 6 \text { au- } \\
\text { thors? Do these journals agree to an acknowledgment paragraph that } \\
\text { would acknowledge the rest of the team? }\end{array}$ & $\begin{array}{l}\text { Lead authors agree on contacting the journals to be targeted for } \\
\text { dissemination prior to manuscript preparation. Journals need } \\
\text { to accommodate the multi-authorship nature of manuscripts } \\
\text { from research consortia }\end{array}$ \\
\hline
\end{tabular}


as well as data access, analysis, and the time factor (time-sensitive issues) which need to be considered when conducting longitudinal studies. Some of the issues in this set related to the psychometric properties of the assessment tools in terms of validity and reliability, in addition to the piloting of instruments in the appropriate languages. The translation of assessment instruments is a major methodological challenge for European research consortia. Translation methods need to be employed that aim to establish equivalence of meaning (36) and the assessment of the same attributes in each cultural group or country (37). Cross-cultural and cross-language equivalence require attention and need to be assessed in instrument translation (38). Yet most existing cross cultural research does not adequately describe translation methods that are used (4).

Further methodological concerns focussed on the need for standardised sampling schemes across the participating countries. The participating institutions and students of each country should preferably also be fairly representative of the countries they originate from if findings are to be generalisable. In addition, this set also revealed concerns in relation to requirements for the ethical approval of the study, which may vary in different countries (3, 39-41). There are legitimate concerns about the confidentiality of the participants' and universities' collected data that need to be addressed (5).

Additionally, many other assorted methodological challenges need consideration by consortia who aim to research similar issues across multiple organisations or countries. For example when surveys are implemented over several years or when follow-up surveys of particular cohorts are intended in order to understand short-term or long-term effects, the time factor needs to be considered. Within this realm, the challenges included the possibility of secular trends, the losses to follow-up, as well as some 'stability' issues that are critical in longitudinal research: the stability of the focus of the study, the assessment tools, and the researcher team (42).

Furthermore, this set of methodological challenges also included a variety of features related to the analyses of the emergent data sets. These comprised the statistical techniques to be employed; the use of multilevel analysis and stratification; the importance of inclusion in the survey of institution-specific variables in order to contrast institutions; as well as the appropriateness of attributing any effect/s to either the characteristics of the specific institution or the country. Some particular suggestions for dealing with these challenges are provided in Table 3 .

The third set of difficulties had to do with the financial aspects of research consortia. These comprised the availability of sufficient funding and whether such funding is likely to be Pan-European or country specific; the flow of finances between countries and institutions; and whether participating countries have compatible or opposing fiscal years. In addition, other concerns were in relation to whether there is adequate budgeting and provision for joint scientific activities and meetings; the challenges associated with different rules and regulations governing the salary scales for researchers in countries with different economic development; and the thorny issue of unequal access to material resources such as hardware and software or human resources $(5,9,43,44)$.

The fourth set of potential obstacles was related to the operational challenges that are encountered in the collaborative nature of research consortia. These included issues of careful planning of joint activities, good participation by all members of the consortium, fair division of labour, democratic decision making, the building of relationships and sustaining them, as well as the integration of new partners as the research consortium is expanding (45). Collaborators in a research consortium rarely assess the process of collaboration (5) and partnership working (46) that usually requires the assessment of the multiple facets of the collaborative practice $(1,47)$.

The fifth set of complexities had to do with the structural challenges as regards the 'shape' of the consortium. These included a range of management, coordination and communication issues as well as leadership. Problems of communication are not uncommon (48-50) and could generate misunderstandings, as well as failures to appreciate important differences among the participating sites (5). Thus, consortia need to set up regular meetings, conference calls, and e-mail contacts, distribute minutes, and agree on and enforce action points and time lines.

Finally, the sixth set of challenges was related to the equitable ownership of data or the unbiased sharing of opportunities for new projects and peer-reviewed dissemination (5). These included queries on who owned which data, whether different datasets were comparable, as well as issues around the planned published outputs and its accompanying plan of authorship. There needs to be agreed rules that clarify data ownership and outline the process of manuscript development and authorship issues early on to clarify expectations, avoid conflicts and duplication of analyses.

\section{CONCLUSION}

Consortia are increasingly employed for clinical and public health research. Therefore, a discussion of benefits, challenges, and solutions may assist in planning and implementing such research collaborations. This paper has contributed to a more comprehensive understanding of the complexities surrounding the work of research consortia. Cross-national consortia can play a role in the reduction in the inequality of resources and research opportunities in the participating countries. However, there are difficulties surrounding the work of consortia that collaborate on conducting research across several sites $(3,5,6,8,9,31,51$, 53). Countries have different languages, traditions of academic cultures and hierarchies, dissimilar rules, regulations and ethical requirements, as well as distinct tax years and personnel recruitment policies. All these challenges and many others will need to be systematically considered and thoroughly addressed in order that a research consortium is fruitful and productive. Authors of this review may have not been aware of additional challenges which aroused in projects undertaken by others. Furthermore, the challenges can increase when worldwide research activities are involved, with more countries participating in the investigations.

Nevertheless, if these anticipated challenges are prevented or solved, the benefits of research consortia can include greater generalisability of findings, a more comprehensive appreciation of the study results than would be possible with a single-site inquiry, and increased probabilities to bring about policy changes. Crossnational research consortia can reduce the inequality of resources and research opportunities. Such consortia deserve the attention of funding agencies and research councils. They have a great potential for synergies that result from the collaborating together 
of large multi-disciplinary investigator teams sharing their diverse strengths and expertise, all working on the same research issue in multiple countries and diverse populations.

\section{Acknowledgments}

In addition to the authors, the Cross National Students Health Study group includes: S. Meier (Germany); N. Bilir, H. Ozcebe, D. Aslan (Turkey); J. Petkeviciene, J. Klumbiene, I. Miseviciene (Lithuania); S. Ilieva (Bulgaria); U. Dudziak (Poland); F. Guillen-Grima (Spain) and others. The 2 day workshop and a 12 month Visiting Professorship (A. Maxwell) at the University of Bielefeld was funded by the German Academic Exchange Service (DAAD). Thanks to S. Priebe for constructive comments on earlier drafts of this manuscript.

\section{REFERENCES}

1. El Ansari W, Phillips CJ, Hammick M. Collaboration and partnerships: developing the evidence base. Health Soc Care Community. 2001 Jul;9(4):215-27.

2. Stock C, Kücük N, Miseviciene I, Guillen-Grima F, Petkeviciene J, Aguinaga-Ontoso I, et al. Differences in health complaints among university students from three European countries. Prev Med. 2003 Dec;37(6 Pt 1):535-43.

3. Greene SM, Hart G, Wagner EH. Measuring and improving performance in multicenter research consortia. J Natl Cancer Inst Monogr. 2005;(35):26-32.

4. Willgerodt MA, Kataoka-Yahiro M, Kim E, Ceria C. Issues of instrument translation in research on Asian immigrant populations. J Prof Nurs. 2005 Jul-Aug;21(4):231-9.

5. Wagner EH, Greene SM, Hart G, Field TS, Fletcher S, Geiger AM, et al. Building a research consortium of large health systems: the Cancer Research Network. J Natl Cancer Inst Monogr. 2005;(35):3-11.

6. Goede H, El Ansari W, editors. Partnership work: the health service-community interface for the prevention, care and treatment of HIV/AIDS. Report of a WHO consultation 5-6 December 2002. Geneva: WHO; 2003.

7. Steenbergen G, El Ansari W. The power of partnership. Stop TB Partnership, World Health Organization. Geneva: WHO; 2003.

8. Kennedy HP, Renfrew MJ, Madi BC, Opoku D, Thompson JB. The conduct of ethical research collaboration across international and culturally diverse communities. Midwifery. 2006 Jun;22(2):100-7.

9. El Ansari W. Collaborative research partnerships with disadvantaged communities: challenges and potential solutions. Public Health. 2005 Sep;119(9):758-70.

10. Corless IB, Nicholas PK, Nokes KM. Issues in cross-cultural quality-oflife research. J Nurs Scholarsh. 2001;33(1):15-20.

11. World Health Organization [database on the Internet]. European health for all statistical database [cited 2007 Jan 4]. Available from: http://www. euro.who.int/hfadb

12. Lopez AD. Assessing the burden of mortality from cardiovascular diseases. World Health Stat Q. 1993;46(2):91-6.

13. Murray JL, Lopez AD. The global burden of disease. Geneva: WHO; 1996.

14. McKee M. Monitoring health in central and eastern Europe and the former Soviet Union. Soz Praventivmed. 2005;50(6):341-3.

15. Steptoe A, Wardle J. Health behaviour, risk awareness and emotional well-being in students from Eastern Europe and Western Europe. Soc Sci Med. 2001 Dec;53(12):1621-30.

16. Steptoe A, Wardle J, Cui W, Baban A, Glass K, Tsuda A, et al. An international comparison of tobacco smoking, beliefs and risk awareness in university students from 23 countries. Addiction. 2002 Dec;97(12):156171.

17. Meier S, Stock C, Krämer A. New approaches of health promotion at universities - Evaluation of a health circle among students. Prävention. 2003;2:53-6. (In German.)

18. Stock C, Guillen-Grima F, de Mendoza JH, Marin-Fernandez B, Aguinaga-Ontoso I, Kramer A. Risk factors of herpes simplex type 1 (HSV-1) infection and lifestyle factors associated with HSV-1 manifestations. Eur J Epidemiol. 2001;17(9):885-90.
19. Stock C, Guillen-Grima F, Prufer-Kramer L, Serrano-Monzo I, MarinFernandez B, Aguinaga-Ontoso I, et al. Sexual behavior and the prevalence of Chlamydia trachomatis infection in asymptomatic students in Germany and Spain. Eur J Epidemiol. 2001;17(4):385-90. Erratum in: Eur J Epidemiol. 2001;17(6):593.

20. Stock C, Kücük N, Miseviciene I, Petkeviciene J, Krämer A. Misperceptions of body shape among university students from Germany and Lithuania. Health Educ. 2004;104(2):113-21.

21. Petkeviciene J, Petrauskas D, Klumbiene J, Miseviciene I, Kardelis K. Sexual behaviour of first year students of Kaunas Universities. Lietuvos akušerija ir ginekologija. 2002;5:185-90. (In Lithuanian.)

22. Kramer A, Prufer-Kramer L, Stock C, Tshiananga JT. Differences in health determinants between international and domestic students at a German university. J Am Coll Health. 2004 Nov-Dec;53(3):127-32.

23. Petrauskas D, Petkeviciene J, Klumbiene J, Siudikiene J. Health behaviour among students of Kaunas universities: dental health and oral hygiene. Stomatologija, Balt Dent Maxillofac J. 2003;5(3):106-9.

24. Uter W, Stock C, Pfahlberg A, Guillen-Grima F, Aguinaga-Ontoso I, Brun-Sandiumenge $C$, et al. Association between infections and signs and symptoms of ,atopic' hypersensitivity-results of a cross-sectional survey among first-year university students in Germany and Spain. Allergy. 2003 Jul;58(7):580-4.

25. Yuen PP, Gould D, Cheng MY. Rationing hospital services in Hong Kong: priority setting by clinicians using the Delphi method. Health Serv Manage Res. 2002 Feb;15(1):1-13.

26. Helmer O. Social technology. New York: Basic Books; 1966.

27. Dalkey N. The Delphi method: an experimental study of group opinion. Santa Monica: Rand Corporation; 1969.

28. Moore CM. Group techniques for idea building. Newbury Park: Sage; 1987.

29. Stewart J, O`Halloran C, Harrigan P, Spencer JA, Barton JR, Singleton SJ. Identifying appropriate tasks for the preregistration year: modified Delphi technique. BMJ. 1999 Jul 24;319(7204):224-9.

30. Campbell SM, Cantrill JA, Roberts D. Prescribing indicators for UK general practice: Delphi consultation study. BMJ. 2000 Aug 12;321(7258):425-8.

31. El-Guebaly N, Atkinson MJ. The practice research network: benefits and limitations. World Psychiatry. 2004 Feb;3(1):56-9.

32. Dean SC, Harper CE, Cappuccio FP, Rink E, Dirckx C, Arnout J, et al; European Collaborative Group of the IMMIDIET Project. The challenges of cross-national research in primary health care across Europe. Fam Pract. 2005 Jun;22(3):341-6.

33. Kearney N, Miller M, Sermeus W, Hoy D, Vanhaecht K. Multicentre research and the WISECARE experience. Workflow Information Systems for European Nursing Care. J Adv Nurs. 2000 Oct;32(4):999-1007.

34. Worthen BR, Schmitz CC. Conceptual challenges confronting cluster evaluation. Evaluation. 1997;3(3):300-19.

35. Sinacore JM, Turpin RS. Multiple sites in evaluation research: a survey of organisational and methodological issues. In: Turpin RS, Sinacore JM, editors. Multisite evaluations. New directions for program evaluation. Series No. 50. San Francisco: Jossey-Bass; 1991. p. 5-18.

36. Eremenco SL, Cella D, Arnold BJ. A comprehensive method for the translation and cross-cultural validation of health status questionnaires. Eval Health Prof. 2005 Jun;28(2):212-32.

37. Tang ST, Dixon J. Instrument translation and evaluation of equivalence and psychometric properties: the Chinese Sense of Coherence Scale. J Nurs Meas. 2002;10(1):59-76.

38. Carroll JS, Holman TB, Segura-Bartholomew G, Bird MH, Busby DM. Translation and validation of the Spanish version of the RELATE questionnaire using a modified serial approach for cross-cultural translation. Fam Process. 2001;40(2):211-31.

39. Macklin R. International research: ethical imperialism or ethical pluralism? Account Res. 1999;7(1):59-83.

40. Bhutta ZA. Ethics in international health research: a perspective from the developing world. Bull World Health Organ. 2002;80(2):114-20.

41. Marshall PA. Human rights, cultural pluralism, and international health research. Theor Med Bioeth. 2005;26(6):529-57.

42. Kania C, Richards R, Sanderson-Austin J, Wagner J, Wetzler H. Using clinical and functional data for quality improvement in outcomes measurement consortia. Jt Comm J Qual Improv. 1996 Jul;22(7):492-504.

43. Rosser WW, Culpepper L, Lam CL, Parkerson G, Poon V, Weel CV. Guidelines for international collaborative research. Fam Pract. 1997 Aug;14(4):330-4. 
44. Mapanga K, Ndlovu R, Mapanga M, Mudokwenyu-Rawdon C, Brooten $\mathrm{D}$, Morris D, et al. A model for international research collaboration. Int Nurs Rev. 1999 Jul-Aug;46(4):117-21.

45. El Ansari W. Stakeholders' perceptions of outcomes in public health educational partnerships. In: Knobler SL, Burroughs T, Mahmoud A, Lemon SM, editors. Ensuring an infectious disease workforce: education and training needs for the 21 st century - workshop summary. Forum on Microbial Threats, Board on Global Health, Institute of Medicine of the National Academies. Washington, DC: The National Academy Press; 2006.

46. El Ansari W, Phillips CJ. Empowering health care workers in Africa: partnerships in health - beyond the rhetoric towards a model. Crit Public Health. 2001 Sep 1;11(3):231-52.

47. Kreuter MW, Lezin NA, Young LA. Evaluating community-based collaborative mechanisms: implications for practitioners. Health Promot Pract. 2000;1(1):49-63.

48. Goodrow B, Olive KE, Behringer B, Kelley MJ, Bennard B, Grover $\mathrm{S}$, et al. The Community Partnerships Experience: a report of institutional transition at East Tennessee State University. Acad Med. 2001 Feb;76(2):134-41.
49. Weiss ES, Anderson RM, Lasker RD. Making the most of collaboration: exploring the relationship between partnership synergy and partnership functioning. Health Educ Behav. 2002 Dec;29(6):683-98.

50. El Ansari W, Phillips CJ, Zwi AB. Public health nurses“ perspectives on collaborative partnerships in South Africa. Public Health Nurs. 2004 May-Jun;21(3):277-86.

51. Abramowitz S, Obten N. Ryan White CARE Act Title IV: building networks to improve healthcare delivery to the HIV infected. AIDS Public Policy J. 2000;15(1):17-28.

52. Renfrew MJ, Raisler J, Powell Kennedy H, Mudokwenyu-Rawdon C, Prakasamma M. Conducting international research in midwifery: a workshop held at the ICM Congress, Vienna, April 2002. J Midwifery Womens Health. 2003 Sep;48(5):346-9.

53. El Ansari W, Maxwell A, Stock C, Mikolajczyk R, Naydenova V, Krämer A. Nurses' involvement in international research collaborations. Nurs Stand. 2007 Mar; 21(6):35-40.

Received January 4, 2007 Accepted February 12, 2007 